\title{
Bacillus macquariensis n.sp., a Psychrotrophic Bacterium from Sub-Antarctic Soil
}

\author{
By BETTY J. MARSHALL AND D. F. OHYE \\ Commonrvealth Scientific and Industrial Research Organization, \\ Division of Food Preservation, North Ryde, N.S.W., Australia
}

(Received 8 November 1965)

\begin{abstract}
SUMMARY
A new species of the genus Bacillus was isolated from Macquarie Island soil. The organism is psychrotrophic, producing spores at temperatures down to and including $0^{\circ}$. The maximum temperature for growth is $\mathbf{2 5}^{\circ}$. Apart from its temperature relations, it most closely resembles $B$. pulvifaciens, but differs from that organism in its ability to produce acid from carbohydrates with ammonium salts as sole nitrogen source and in its inability to hydrolyse casein or gelatin, to grow on soybean agar or to grow in $5 \% \mathrm{NaCl}$. The name Bacillus macquariensis is proposed.

Vegetative organisms stained Gram-negative at all stages of growth. Electron micrographs revealed cell-wall structures typical of Grampositive bacteria; on the other hand, chemical analyses demonstrated in cell-wall preparations a wide range of amino acids and relatively low amounts of amino sugars, as commonly found in Gram-negative species.
\end{abstract}

\section{INTRODUCTION}

The range of bacteria capable of growth at low temperatures (psychrotrophs; Eddy, 1960) is wide, and includes Gram-positive and Gram-negative rods and cocci. There appear to have been no reports of the isolation of aerobic bacteria sporing at $0^{\circ}$, although Sinclair \& Stokes (1964) have reported the isolation of strictly anaerobic psychrotrophic spore-forming bacteria from soil, mud and sewage. This report describes the isolation and properties of a facultatively anaerobic bacterium, capable of growth and sporulation at $0^{\circ}$, from sub-Antarctic soil.

\section{METHODS}

Isolation of the organism. Suspensions $(10 \%, \mathrm{w} / \mathrm{v})$ of soil from Macquarie Island (latitude $54^{\circ} 29^{\prime} \mathrm{S}$; ; longitude $158^{\circ} 58^{\prime} \mathrm{E}$ ) were prepared in saline and heated for $10 \mathrm{~min}$. at $80^{\circ}$ to destroy vegetative forms. Suitable dilutions were plated on brain + heart and nutrient agars, and the plates incubated at $20^{\circ}$ and at $1 \cdot 1^{\circ}$. Colonies were more discrete on nutrient agar, and after 3 weeks at $1 \cdot 1^{\circ}$ were picked from this medium and transferred to nutrient broth. After growth at $20^{\circ}$ in this medium each culture was streaked on nutrient agar again and re-isolated.

Physiological tests. Growth in nutrient broth was poor, and for the determination of growth and sporulation at various temperatures isolates were inoculated onto agar slopes of potato infusion plus inorganic salts $\left(\%, \mathrm{w} / \mathrm{v}: \mathrm{MnSO}_{4} .5 \mathrm{H}_{2} \mathrm{O}, \mathbf{0} \cdot 002\right.$; $\mathrm{MgSO}_{4} .7 \mathrm{H}_{2} \mathrm{O}, 0.04 ; \mathrm{ZnSO}_{4}, 0.003 ; \mathrm{CuSO}_{4} .5 \mathrm{H}_{2} \mathrm{O}, 0.001 ; \mathrm{FeSO}_{4} .7 \mathrm{H}_{2} \mathrm{O}, 0.001$; $\left.\mathrm{CaCl}_{2}, 0.01 ; \mathrm{K}_{2} \mathrm{HPO}_{4}, 0.05\right)$. 
In studying the morphological and growth characteristics of the isolates, the methods and media described by Smith, Gordon \& Clark (1946) were used. The incubation temperature for these tests was $20^{\circ}$.

To prepare spore suspensions for the determination of heat resistance, vegetative organisms were removed by incubation with papain $(1 \mathrm{mg} . / \mathrm{ml}$. of suspension) at $7 \cdot 5^{\circ}$ for 10 days.

\section{Cell-wall analyses}

Preparation. Organisms were grown in brain + heart broth with aeration by shaking for 4 days at $20^{\circ}$. No sporulation occurred in this medium. After harvesting and washing twice with saline, organisms were disintegrated by treatment for about $80 \mathrm{~min}$. with ballotini beads $\left(0 \cdot 1 \mathrm{~mm}\right.$. diam.) in a reciprocating shaker at $1 \cdot 1^{\circ}$. When heated organisms were used, contaminating cytoplasm and debris from the wall preparation could not all be removed. Hence viable organisms were disintegrated without previous heating. For heated and unheated organisms, the amino sugars present in the supernatant fluid fractions after disintegration and centrifugation were 0.06 and $0.08 \%$ dry wt., respectively, thus indicating no significant autolysis of the unheated cell walls during this process. The crude wall preparations were purified by the method of Salton (1964), and freeze-dried when electron micrographs showed that the preparations were free from cytoplasm. Chemical analyses were made on these freeze-dried cell walls.

Nitrogen content was determined on triplicate samples by the method of Johnson (1941) after digestion by the Kjeldahl procedure.

Phosphorus was estimated colorimetrically by the method of Allen (1940).

Lipid content was determined by ether extraction after hydrolysis of the walls with $6 \mathrm{~N}-\mathrm{HCl}$ for $2 \mathrm{hr}$ at $100^{\circ}$.

Amino sugars were estimated by the colorimetric method of Rondle \& Morgan (1955) after hydrolysis of the wall preparations in sealed ampoules with $2 \mathrm{~N}-\mathrm{HCl}$ for $2 \mathrm{hr}$ at $100^{\circ}$.

Identification of cell-wall constituents by paper chromatography. Amino acids and amino sugars were identified after two-dimensional paper chromatographic separation (Whatman paper no. 1 , pyridine + water; $4+1$ by vol.; $n$-butanol + glacial acetic acid + water; $6+1+2$, by vol.) of $6 \mathrm{~N}-\mathrm{HCl}$ hydrolysates $\left(24 \mathrm{hr}\right.$ at $\left.100^{\circ}\right)$. To estimate relative molecular proportions of amino acids, chromatograms were dipped in ninhydrin solution $(5 \%, \mathrm{w} / \mathrm{v}$, in acetone + phosphate buffer; $9 \cdot 5+0 \cdot 5$, by vol.), the colours eluted with a mixture of acetone + water $(3+1$, by vol.) and the extinctions measured at $570 \mathrm{~m} \mu$.

Electron microscopy. Samples were fixed overnight in $1 \%$ osmium tetroxide (or for $2 \mathrm{hr}$ in $0.6 \% \mathrm{KMnO}_{4}$ ), soaked in uranyl acetate for $2 \mathrm{hr}$, dehydrated by passage through graded concentrations of ethanol up to $100 \%$, and embedded in Araldite. Sections cut with a Porter-Blum microtome fitted with a diamond knife were examined with a Siemens Elmiskop 1 electron microscope.

\section{RESULTS}

Three of the four samples of Macquarie Island soil yielded psychrotrophic aerobic spore-forming bacteria. On primary isolation, similar numbers of colonies developed in 3 weeks at $1 \cdot 1^{\circ}$ as in 4 days at $20^{\circ}$, and they represented about $1 \%$ of the viable 
bacteria present in the soils before the heat treatment. The twelve isolates studied appeared to be the same organism, a slender Gram-negative rod with a subterminal ellipsoidal spore which swelled the sporangium (Pl. 1, fig. 1).

The bacteria grew at $0^{\circ}$ within 3 weeks. Cultures incubated at $0^{\circ}$ were immersed in a water + ice bath which controlled the temperature to within $0 \cdot 1^{\circ}$. The optimum temperature for growth was $15-20^{\circ}$ and the maximum about $25^{\circ}$; no isolate grew at $30^{\circ}$. On agar slopes, sporulation began after 4 days at $20^{\circ}$, yielding $80-90 \%$ of mature spores after 10 days. In aerated broth cultures only $10 \%$ of the organisms produced mature spores, although $90 \%$ showed early stages of sporulation. At $0^{\circ}$, sporulation began after 4-5 weeks; 5-10\% of mature spores were present after $7 \cdot 5$ weeks on potato infusion + salts agar. This low spore yield did not increase on continued incubation. However, incubation at $1 \cdot 1^{\circ}$ for 10 weeks increased spore production to $50 \%$.

The heat resistance of the spores was relatively low. Spores produced at $1 \cdot 1^{\circ}$ were more heat labile $\left(\mathrm{D}_{800}=12.8 \mathrm{~min}\right.$. $)$ than those formed at $20^{\circ}\left(\mathrm{D}_{800}=17.5 \mathrm{~min}\right.$. $)$. The numbers of colonies formed on agar were the same whether plates were incubated at $20^{\circ}$ or $1 \cdot 1^{\circ}$. This was true with both heated and unheated suspensions.

\section{Characters}

The morphological and general properties of the twelve isolates were the same and are summarized as follows:

Morphology. Vegetative rods of average size $0 \cdot 5 \times 4-6 \mu$ with rounded ends, occurring singly. The rods are motile. Gram-negative at all stages of growth. The sporangium is swollen; spindle-shaped to clavate. Average spore size in Gramstained preparations $1.0-1.5 \times 1 \cdot 5-2 \mu$, ellipsoidal, subterminal, with remnants of sporangium usually adhering. Spore wall easily stained.

Nutrient agar. After 4 days at $20^{\circ}$, colonies small, discrete, opaque, smooth with translucent, fimbriate edges, $0 \cdot 5-1 \cdot 0 \mathrm{~mm}$. diameter.

Nutrient agar slope. After 4 days at $20^{\circ}$, scant, greyish-white growth, smooth, translucent to slightly opaque.

Glucose agar slope. Growth slightly heavier than on nutrient agar.

Nutrient broth. Growth poor, with sedimentation. Vigorous aeration markedly increases growth.

$p H$ value of glucose broth culture: $\mathrm{pH} 5 \cdot 4-5 \cdot 8$ after 7 days at $20^{\circ}$.

$\mathrm{NaCl}$ broth. Growth in $2 \%$ but not in $5 \% \mathrm{NaCl}$.

Potato. Growth spreading; thin, glistening, no pigmentation.

Indole. Not produced.

Crystal violet broth. No growth in $1 / 1,000,000$ crystal violet.

Soybean agar slopes. No growth.

Fermentation tests. Acid but no gas (with ammonium salts as nitrogen source) from glucose, xylose, ribose, galactose, lactose, sucrose, maltose, salicin, mannitol.

Metabolism. Aerobe, facultative anaerobe. Optimal growth $15-20^{\circ}$, no growth at $30^{\circ}$. Growth and sporulation at $0^{\circ}$. Growth in glucose broth under anaerobic conditions pH 5.6-5.8.

Voges-Proskauer reaction. Negative.

Nitrate reduction to nitrite. Negative.

Urease. Negative. 
Catalase. Positive.

Starch hydrolysis. Negative.

Gelatin hydrolysis. Negative.

Methylene-blue reduction. Negative.

Nutrition. Will not produce spores in brain + heart infusion medium. Spores formed in nutrient broth and agar, potato infusion + salts agar, potato slopes, and glucose + ammonium salts medium. Yield of organisms in all broth media is greatly increased by vigorous aeration.

\section{Electron microscopy}

The Gram-negative property of this organism was exhibited in all phases of growth, even before cell division had occurred after germination. However, electron micrographs of thin sections (Pl. 1, fig. 2) showed the boundary layers of the vegetative form to consist of a relatively thick outer wall and a thin inner membrane. These correspond in their dimensions to the structural cell wall and the cytoplasmic membrane of Gram-positive bacteria, and differ markedly from the configuration considered typical of the Gram-negative bacteria, with its outer limiting unit membrane.

The mature spore is shown in thin section in Pl. 1, fig. 3. Its structures include the normal laminated inner coat and dense outer coat, the latter exhibiting a pronounced ridge structure reminiscent of Bacillus polymyxa (Holbert, 1960). The mature spore usually remains within the sporangium.

\section{Chemical analysis of cell roalls}

In view of the apparent conflict between data obtained from the Gram staining reaction and from electron micrographs, chemical analyses were made on preparations of the cell walls of vegetative forms. The results, given in Table 1 , are the means of three determinations on each of three isolates of the organism. The appearance of cell walls prepared for analysis is shown in the electron micrograph of Pl. 1, fig. 4. The amino acids and amino sugars identified in the acid hydrolysate, and their relative molecular proportions, were: alanine (5), lysine (5), proline (4), glutamic acid (4), diaminopimelic acid (4), serine (3), aspartic acid (3), isoleucine/leucine (3), valine (3), tyrosine (2), methionine (2), cysteine (2), glycine (2), threonine (2), glucosamine (1), muramic acid (1).

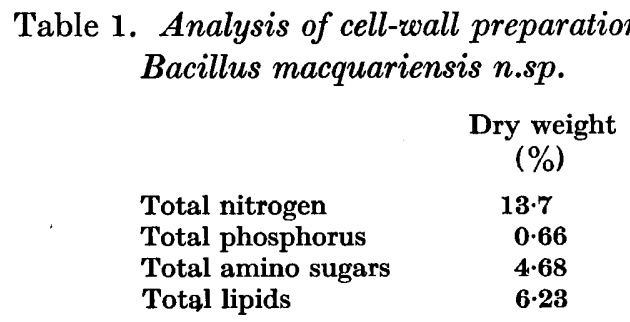

\section{DISCUSSION}

Bergey's Manual (1957) divides the genus Bacillus into three morphological groups. The new species Bacillus macquariensis produces a terminal ellipsoidal spore which swells the sporangium, and therefore belongs to the morphological group 2. 
Comparison with the named species within this group shows that the new isolate most closely resembles $\boldsymbol{B}$. pulvifaciens. However, $\boldsymbol{B}$. macquariensis can be distinguished from $B$. pulvifaciens by a number of characters, of which the following are among the more important.

(i) While the optimum temperature for growth of Bacillus pulvifaciens is $37^{\circ}$ (with poor growth at $28^{\circ}$ ), the organism now described has a temperature range of $\mathbf{0 - 2 5 ^ { \circ }}$, the optimum for growth being $15-20^{\circ}$. Its ability to grow and to produce spores at low temperatures distinguishes it not only from $B$. pulvifaciens but from all named species in the genus.

(ii) The vegetative forms of Bacillus macquariensis are Gram-negative at all stages. Growth on nutrient agar is scant, smooth, and greyish white. Addition of glucose to this medium increases growth slightly. Growth in nutrient broth is also very scant, but is greatly increased by vigorous aeration. Availability of oxygen may also be important in sporulation, as the percentage of mature spores formed on agar slope cultures exceeded that produced in liquid cultures, even when the latter were aerated vigorously.

(iii) The new species, unlike Bacillus pulvifaciens, can utilize ammonium salts as sole nitrogen source, will not grow on soybean slopes, will not hydrolyse gelatin or casein, nor grow in presence of $5 \% \mathrm{NaCl}$.

It is of interest that this organism, Gram-negative under all conditions and very sensitive to crystal violet, possesses a cell wall and membrane structure usually associated with Gram-positive bacteria. Cell-wall preparations, which appeared in electron micrographs to be virtually free from cytoplasmic membrane, had a chemical composition which was not, from the tabulated summaries of Salton (1963), completely typical of either Gram-positive or Gram-negative bacteria. However, the low mucopeptide content (as shown by the amino sugar value) and the wide range of amino acids present, correspond to analyses of bacteria which are Gram-negative.

The name Bacillus macquariensis is proposed for this new species, and is derived from the location of soils from which it was isolated. Three isolates have been deposited at the National Collection of Type Cultures, the type strain being NCTC 10419.

We are indebted to Dr F. Jacka, of the Antarctic Division of the Department of External Affairs, for the Macquarie Island soil samples; to Mr P. R. Maguire for the light micrographs; and to Dr W. J. Scott for his interest and advice.

\section{REFERENCES}

Alles, R. J. L. (1940). Estimation of phosphorus. Biochem. J. 34, 858.

Bergey's Manual of Determinative Bacteriology (1957). 7th ed. Ed. by R. S. Breed, E. G. D. Murray and N. R. Smith. Baltimore, U.S.A.: Williams and Wilkins.

EDDY, B. P. (1960). The use and meaning of the term 'psychrophilic'. J. appl. Bact. 23, 189. Holbert, P. E. (1960). An effective method of preparing sections of Bacillus polymyxa sporangia and spores for electron microscopy. J. biochem. biophys. Cytol. 7, 373.

Johnson, M. J. (1941). Isolation and properties of a pure yeast polypeptidase. $J$. biol. Chem. 137, 575.

Rondle, C. J. M. \& Morgan, W. T. J. (1955). The determination of glucosamine and galactosamine. Biochem. J. 61, 586.

SALton, M. R. J. (1963). The relationship between the nature of the cell wall and the Gram stain. J. gen. Microbiol. 30, 223. 
Salton, M. R. J. (1964). The Bacterial Cell Wall. Amsterdam, N.Y.: Elsevier Publ. Co. SinclaIr, N. A. \& Stokes, J. L. (1964). Isolation of obligately anaerobic psychrophilic bacteria. J. Bact. 87, 562.

Smith, N. R., Gordon, R. E. \& Clark, F. E. (1946). Aerobic, mesophilic, spore-forming bacteria. Misc. Publs U.S. Dep. Agric. no. 559.

\section{EXPLANATION OF PLATE}

Fig. 1. Photomicrograph of a Gram-stained film of Bacillus macquariensis n.sp.; $\times \mathbf{2 0 0 0}$.

Fig. 2. Electron micrograph of a vegetative form of Bacillus macquariensis n.sp.; $\times 60,000$.

Fig. 3. Electron micrograph of a mature spore of Bacillus macquariensis n.sp.; $\times 110,000$.

Fig. 4. Electron micrograph of a vegetative cell-wall preparation of vegetative Bacillus macquariensis used for chemical analysis; $\times 30,000$. 
Journal of General Microbiology, Vol. 44, No. 1

Plate 1

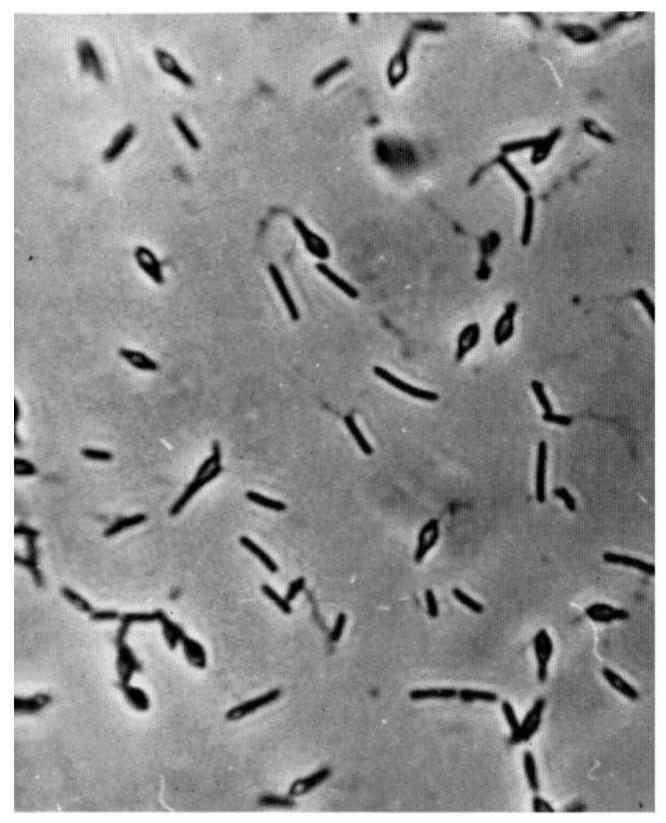

Fig. 1

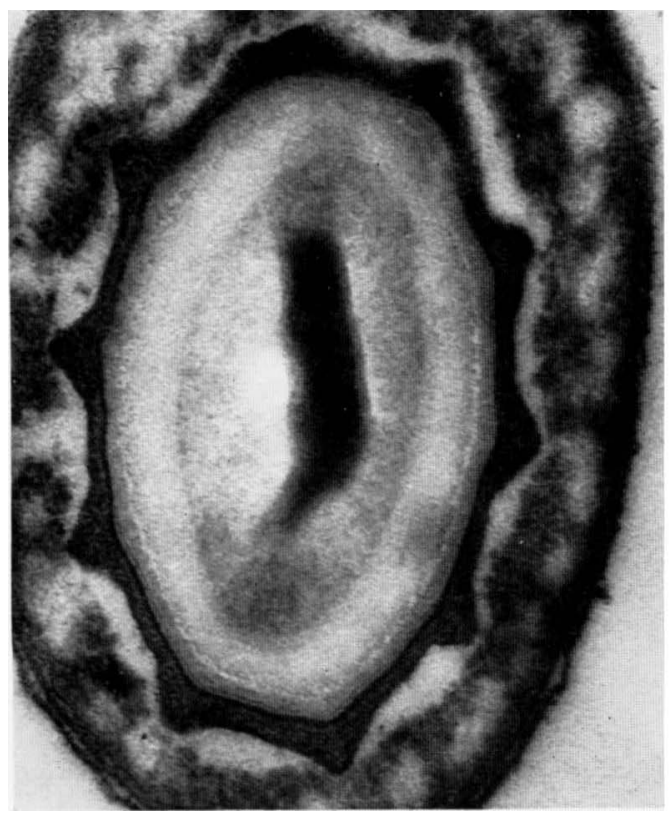

Fig. 3
B. F. MARSHALL AND D. F. OHYE

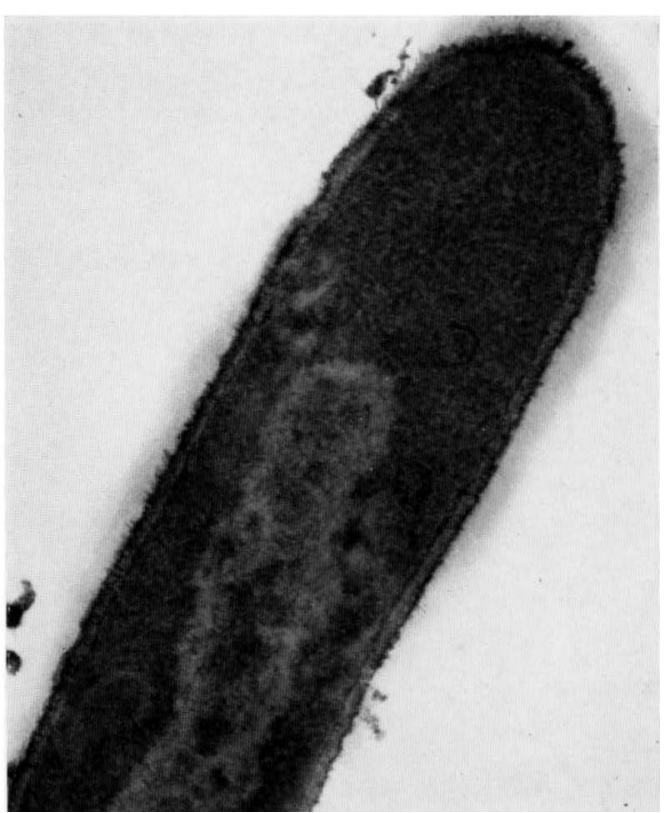

Fig. 2

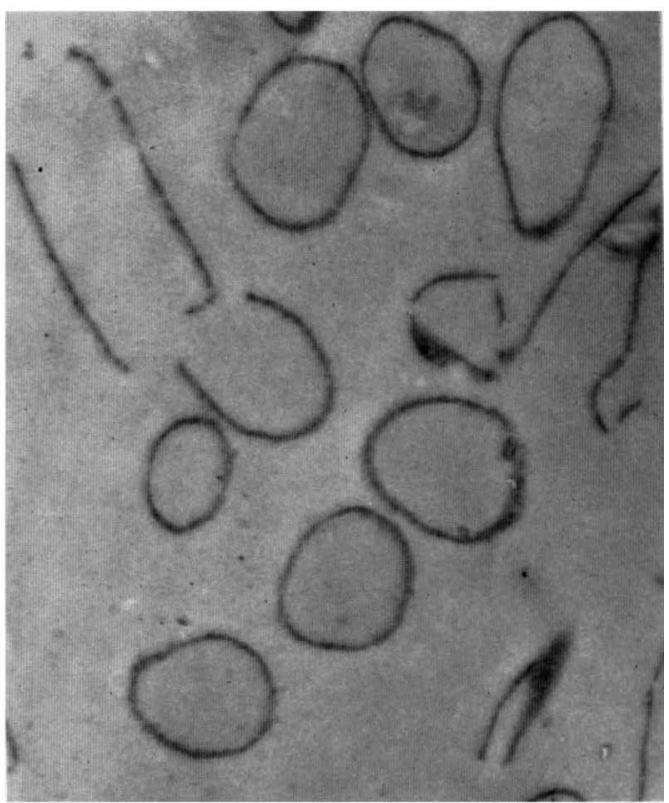

Fig. 4

(Facing p. 46) 